\title{
Formal Financial Credit Constraints and Solutions for Entrepreneurial Farmers
}

\author{
Xiaoyan Zhang \\ Division of Finance, School of Economics, Jinan University, Guangzhou, China \\ Email: Zhangxy_211@163.com
}

How to cite this paper: Zhang, X.Y. (2018) Formal Financial Credit Constraints and Solutions for Entrepreneurial Farmers. Modern Economy, 9, 2268-2282. https://doi.org/10.4236/me.2018.912140

Received: November 16, 2018 Accepted: December 24, 2018 Published: December 27, 2018

Copyright $\odot 2018$ by author and Scientific Research Publishing Inc. This work is licensed under the Creative Commons Attribution International License (CC BY 4.0).

http://creativecommons.org/licenses/by/4.0/

\begin{abstract}
With the deepening of China's economic reforms, in the process of gradual diversification of farmers' incomes, the income growth brought by farmers' entrepreneurship plays an important role in increasing farmers' income. The importance of formal financial support for entrepreneurial farmers is self-evident. However, due to various factors between entrepreneurial farmers and formal financial institutions, the supply and the demand of formal financial credits of entrepreneurial farmers are unbalanced. This paper firstly analyzes the formation of formal financial credit constraints of entrepreneurial farmers by combining the current situation of supply and demand of formal financial credits of entrepreneurial farmers, and then proposes countermeasures to alleviate the formal financial credit constraints of entrepreneurial farmers.
\end{abstract}

\section{Keywords}

Formal Financial Institutions, Entrepreneurial Farmers, Credit Constraints, Mortgage Guarantees, Risk Control

\section{Introduction}

The Fifth Plenary Session of the 18th Central Committee of the Communist Party of China mentioned that it is necessary to help poor rural households in rural areas escape the poverty situation according to existing standards in China, thus solving the regional overall poverty in China [1]. With the deepening of China's economic reforms, in the characteristics of farmers' incomes showing diversification, the income growth brought by farmers' entrepreneurship has increased the income of farmers and realized the poverty alleviation of farmers. However, the current rural areas face the problem of shortage of funds, and the credit constraint is more common. How to effectively alleviate the credit con- 
straints in rural areas has become the focus of domestic scholars. Although formal financial institutions and informal financial institutions are involved in rural lending under market conditions, studies have shown that even considering informal financial institutions, a large proportion of rural households' credit needs are not being met, in extreme cases. Farmers have profitable projects but lose opportunities due to lack of collateral and guarantees and insufficient funds. Li Rui and Zhu Xi (2007) have shown that the degree of rural financial restraint in China is 70.92\%. The results of Yu Quansheng and Zhou Yahong (2014) are quite different from those of the former, but the results show that the intensity of rural credit restraint in China is still as high as $14.4 \%$. And the credit constraint has obvious effect on the welfare loss of farmers. The main reasons for this situation are: on the one hand, the loan interest rate of formal financial institutions is lower than the market interest rate of microfinance institutions; the amount of funds provided by formal financial institutions is limited; and the formal credit demand of borrowers cannot be fully satisfied; On the one hand, if financial institutions only issue loans to farmers engaged in agricultural production after taking deposits, their profitability is limited. Therefore, financial institutions tend to invest most of their funds in non-agricultural enterprises with strong profitability, resulting in rural areas. The transfer of funds to cities and enterprises further aggravates the credit constraints of farmers.

\section{Literature Review}

The credit financing of entrepreneurial farmers has become the focus of academic circles and has achieved many theoretical results. The relevant results are summarized as follows.

\subsection{Research on the Status Quo of Formal Financial Credit for Entrepreneurial Farmers}

Zhang Yingliang and Gao Jing [2] used 939 samples of entrepreneurial farmers to analyze the formal financial constraints of entrepreneurial farmers and their causes. Through exploration, entrepreneurs have a greater desire to obtain credit support for rural formal finance, but more than half of entrepreneurial farmers face the dilemma of formal financial repression. At the same time, the study shows that the financial restraint of farmers in different stages of entrepreneurship is not the same. For example, in the stage of entrepreneurial development, entrepreneurial farmers hope to obtain more formal financial credit support to develop and expand the existing achievements, but because they can't pass the bank's review because they have insufficient assets to guarantee the mortgage, they are at this stage. The entrepreneurial farmers are mainly faced with supply-type financial restraint. Based on this, the research puts forward the model of "credit financing, project financing, and co-financing", in order to help entrepreneurs to get out of the mortgage financing dilemma.

Shi Longjing [3] took the phenomenon of formal financial credit rationing of Guanzhong farmers in Shaanxi as the research object. The conclusions of the 
study are as follows: 1) Farmers in Guanzhong area have higher demand for formal credit, but it is difficult to obtain loans from formal financial institutions, and the formal financial credit ratio is as high as $88.04 \%$; 2) household cultivated land area, household head Gender, family labor burden rate, etc. have a positive and significant impact on the formal financial credit demand of farmers; 3 ) family member composition, household head education level, family annual income, whether there is deposit in formal financial institutions, and negative demand for formal financial credit of farmers Significant influence; 4) family member composition, household head education level, family annual income, whether deposits in formal financial institutions have a negative impact on the formal financial credit needs of farmers; 5) family cultivated land area and family labor burden rate are regular The supply of loans to financial institutions has a negative impact; 6) the age of the head of the household, the proportion of various types of income, the level of understanding of microfinance, the way to understand loan information, and the number of financial outlets in the village Credit needs of rural formal financial institutions or formal financial institutions Decision issued had no significant effect on.

\subsection{Esearch on the Factors Restricting Entrepreneurial Farmers' Access to Formal Financial Credit}

Zhang Linxiu, Zhang Bing [4] and others used sample survey data to show that the formal financial credit service innovation of entrepreneurial farmers in recent years has not achieved considerable results, and informal financial credit is still an important source of channels. Formal financial institutions are gradually reducing the formal credit supply. The paper also proposes that the age of entrepreneurial farmers, the annual income of the family and the use of the borrowed funds are the key factors that restrict the entrepreneurs' ability to obtain the required loans.

Lu Yajuan, Zhang Longyao [5] and others believe that for rural families in China, the entrepreneurial development of farmers in their non-agricultural sectors will be affected by the existence of formal financial restraint, if the formal financial availability of farmers is improved. Increasing the chances of farmers' entrepreneurship will have a positive positive marginal effect. Therefore, they proposed that in the next stage of development, the key to improving the entrepreneurship level of rural households in China and encouraging farmers to start their own businesses is to gradually reduce the threshold for formal financial credits of entrepreneurial farmers in China, by increasing townships, especially rural areas. The formal financial credit supply for regional entrepreneurs meets the demand for credit funds of more entrepreneurial farmers.

Chen Ci, Zhou Liandi [6] and others based on the farmer's livelihood capital framework, based on the research results of comprehensive scholars, the current impact factors of China's farmer financing status are summarized into the following categories: loan interest rate, household material capital, family capital capital five aspects of family human capital and family social capital. 


\subsection{Research on the Causes of Formal Financial Credit Constraints of Entrepreneurial Farmers}

Although farmers' entrepreneurship has been supported by the government in recent years, the government has also introduced many policies to benefit farmers. However, due to some objective factors, the demand and supply of funds for farmers' entrepreneurship are not balanced.

Ping Xinqiao, Zhang Haiyang [7] and others analyzed the causes of financial repression in rural areas of China through the data of farmers in the six provinces collected by their own Chinese rural financial surveys. The results show that: according to the current development status of rural areas in China, Limited liability is still a key cause of imperfect financial market in rural areas of China and financial constraints. At the same time, another cause of imperfections in China's rural financial markets is the existence of moral hazard in rural areas of China. The low level of assets limits the scale of lending by entrepreneurial farmers in rural formal financial institutions.

Black \& Btrahan [8] analyzed the impact of formal financial restraint on China's entrepreneurial activities, indicating that a sound financial lending market coupled with sufficient entrepreneurial credit support will help accelerate the formation of entrepreneurial activities in China and the development of enterprises.

Chen Caiyu [9], through the study of existing survey data, believes that more and more rural household funds flow into the city is the root cause of the difficulty of obtaining the required credit for entrepreneurial farmers and small and medium-sized enterprises in China, and the ability of entrepreneurial farmers and small and medium-sized enterprises to resist various risks. Poor and insufficient credit is the key cause of "difficulty in loans". Insufficient mortgage guarantee is the direct cause of the difficulty of loan. At the same time, according to the current situation of the "difficult" problem, corresponding measures and suggestions are put forward.

Ma Jiujie [10] from the perspective of formal financial credit constraints, found that the social capital stock of farmers has a significant mitigation effect on alleviating the credit constraints on farmers.

In summary, the academic community has made a detailed description of the choice of farmers' financial lending behavior, and has also studied its causes, and proposed solutions to the existing problems. However, according to the research of domestic scholars, most of them are based on a certain province or county, and they are not general. The main subjects involved are the borrowing of funds by farmers, and there is less detailed research on the group of entrepreneurial farmers. As the group of entrepreneurial farmers becomes more and more prominent in the increase of farmers' income, it is of great significance to study the formal financial credit constraints of entrepreneurial farmers and propose solutions. This paper starts with the status quo of formal financial credit of entrepreneurial farmers, and analyzes the causes and solutions of the current situation. Compared with the existing literature, the shortcoming of this paper is that 
it does not prove the formal financial credit constraints of entrepreneurial farmers from the perspective of empirical evidence.

\section{The Status Quo of Supply and Demand of Formal Financial Credit for Entrepreneurial Farmers}

\subsection{Entrepreneurial Farmers and Formal Financial Credit}

For rural households in China, entrepreneurship can further accelerate the transfer of surplus labor in rural areas of China, promote the growth of non-agricultural industries and the transformation of traditional agriculture, and help to promote China's agricultural modernization, rural industrialization and urbanization [11]. However, there are many difficulties in the entrepreneurship of farmers in China. The most critical issue is the financing of funds and funds. According to the current financial market environment in rural areas in China, the main ways to obtain loans for entrepreneurial farmers are usually formal financial channels and informal financial channels. Formal finance includes formal financial institutions such as rural credit cooperatives and commercial banks; informal financial institutions are usually composed of various forms of human capital exchanges between neighboring friends and various forms of mutual assistance (such as clubs) in rural areas. There are even some rural areas where there are still sources of funds such as usury.

\subsection{Demand and Supply of Formal Financial Credit for Entrepreneurial Farmers}

\subsubsection{The Formal Financial Credit Needs of Entrepreneurial Farmers}

With the deepening of China's rural economic reforms, the number of entrepreneurial households has been increasing, and the scale of their entrepreneurial operations has continued to expand. As a result, the demand for entrepreneurial funds required by farmers has continued to increase.

According to the 2013 CHFS survey data, the demand for formal financial lending for entrepreneurial households in rural China has gradually increased, and the ratio of entrepreneurial households with capital loans has increased to $19.6 \%$. Among them, the proportion of productive borrowing in households with low rural income in China is $52 \%$. Only $27.6 \%$ of the entrepreneurial households with financial needs in rural areas can get what they want, which is still a certain gap from China's average of $40.5 \%$. However, further research found that $62.7 \%$ of the $72.4 \%$ of the entrepreneurial households that failed to obtain formal financial credit had no credit willingness to the formal financial institutions despite the credit demand in the entrepreneurial process, and only 9.8\% of the rural households Formal financial institutions have proposed credit willingness, but they have been rejected by formal financial institutions.

Although, since 2014, the central government has repeatedly implemented the policy of lowering interest rate cuts in order to reduce the borrowing costs of physical enterprises and entrepreneurial farmers. However, due to various factors such as information asymmetry, entrepreneurial farmers often do not get 
the required funds. Therefore, at the stage of continuous development of farmer entrepreneurship, entrepreneurial farmers began to seek financial support from multiple channels due to their limited funds. According to incomplete survey statistics, new types of rural business entities such as large grain farmers and farmer cooperatives, the proportion of venture capital raised by relatives and friends reached $45 \%$, rural credit cooperative loans accounted for $40 \%$, and loans from Agricultural Bank and Postal Savings Bank. The ratio is about 10\%, and the proportion of borrowed funds through usury and microfinance companies is relatively low (see Figure 1) [12].

\subsubsection{Entrepreneurial Farmers' Formal Financial Credit Supply}

With the continuous deepening of rural finance in China, China's rural areas have gradually formed a rural financial service framework that integrates policy finance, cooperative finance, and commercial finance. The financial infrastructure of rural areas in China is also gradually improving. The supporting role of entrepreneurial farmers' growth has become more and more obvious [13]. Since 2003, China has begun to promote a new round of reform of rural credit cooperatives. In recent years, China's new micro-financial institutions in rural areas have experienced rapid growth. By the end of 2017, there were 1562 rural banks in China, and as of the end of March 2018, there were 8471 small loan companies nationwide. The rapid development of new rural microfinance institutions in recent years has made the formal financial service organization system of rural areas more diversified (Figure 2).

Recent years, in order to open up the last mile of serving the "three rural", the expansion of the Agricultural Bank of China, which is one of the four traditional banks in China, has gradually accelerated in the financial service network in rural areas. However, other commercial banks such as Industrial and Commercial Bank of China and Bank of China have not increased their investment in financial services in rural areas. In fact, according to the "China Rural Financial Development Report 2014", in the rural households in China, the formal financial institutions that the bank opened into the top three are, in turn, the Rural Credit Cooperative, the Agricultural Bank of China, and the Postal Savings Bank. At the same time, the report shows that the number of bank outlets near rural households in China's rural areas is significantly different from the average number of bank outlets in the neighborhood of the city. The former is 0.77 , while the latter has an average of 2.63 .

\subsubsection{Entrepreneurial Farmers' Formal Financial Credit Supply and Demand Imbalance}

Overall, although the accelerated growth of new rural microfinance institutions has made the financial services of rural areas in China more diversified, there is still a huge difference between the credit needs of entrepreneurial farmers in China and the loan supply of formal financial institutions. That is to say, the financing willingness of the entrepreneurial farmer does not match the credit supply of the market, and some entrepreneurial farmers who have the willingness 


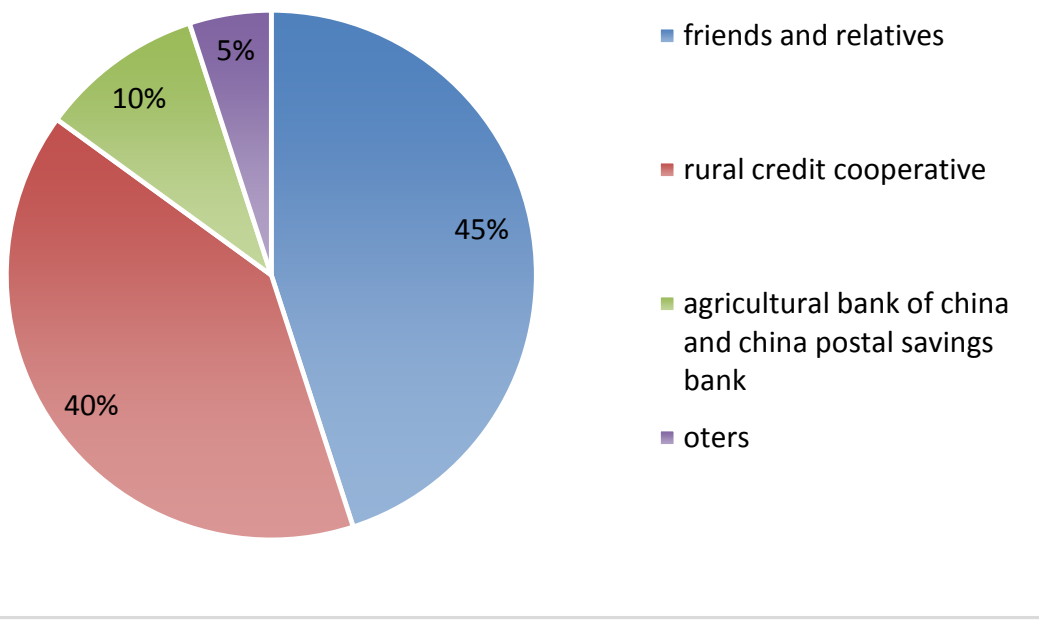

Figure 1. Proportion of sources of funding for entrepreneurial farmers.

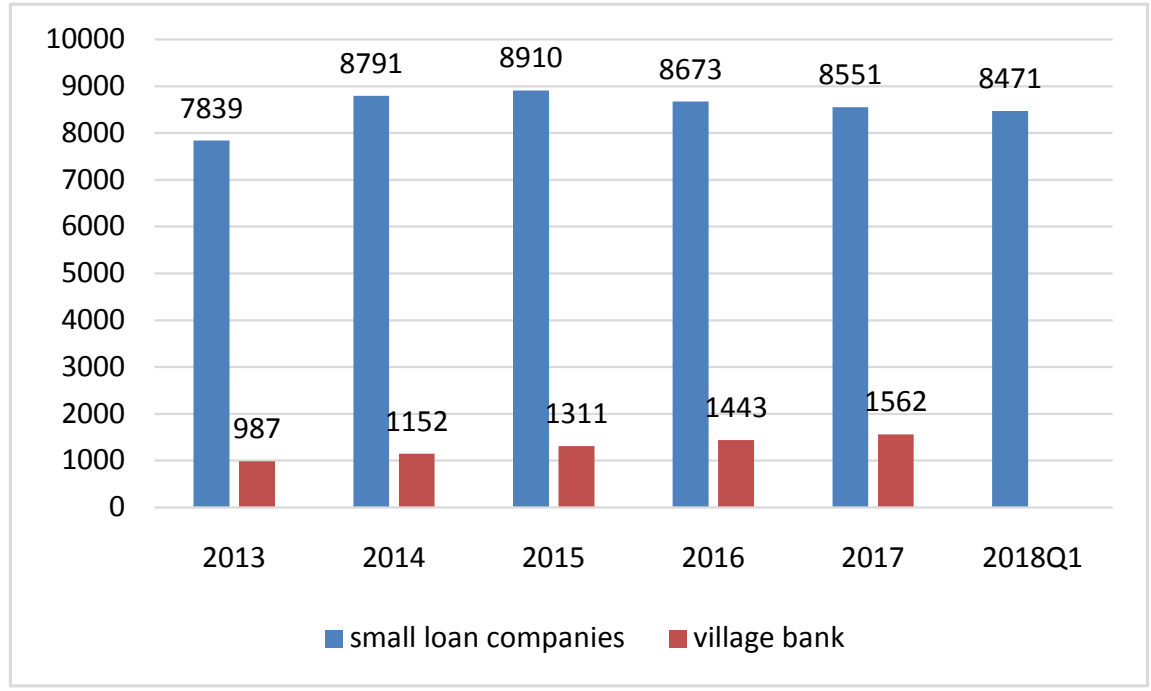

Figure 2. Changes in the number of Chinese village banks and microfinance companies in unit (home). Source of data: According to the data of the China Banking Regulatory Commission and the People's Bank of China.

to finance are excluded by the formal financial institutions, thus failing to enjoy the various rural financial services given by the formal financial institutions in China. The "incremental" reform of the new rural financial institutions that began in China since 2006 is mainly aimed at solving the problem of the quantity and structure of the credit needs of rural financial entities. At present, the problem of credit demand and supply imbalance between entrepreneurial farmers and formal financial institutions in China is reflected in the impact of the rural credit market and the supply side. There is a contradiction between the growing credit demand of rural entrepreneurial farmers and the "fear of lending" and "reluctance to lend" of formal financial institutions. According to the survey, in the case of formal financial restraint, more than $60 \%$ of entrepreneurial farmers 
suffer formal financial restraint, and the financial constraints suffered by farmers with faster development of entrepreneurial activities are more obvious [14]. At the same time, due to the high credit risk of financial business in rural areas in China and the high investment cost, formal financial institutions are more cautious in involvement in this field, which seriously affects the supply capacity of rural formal financial institutions. Therefore, the gap between the weak rural formal financial credit and the growing formal financial credit services of entrepreneurial farmers is self-evident.

\section{The Formation of Formal Financial Credit Constraints for Entrepreneurial Farmers}

The essence of the financial credit constraint of entrepreneurial farmers refers to the ability of farmers to obtain credit lines. In other words, it means that the capital needs of farmers in the process of starting a business cannot be fully supplied. In the previous article, the status quo of the formal financial credit supply and demand of entrepreneurial farmers has been analyzed. It can be seen that there are currently formal financial credit constraints of entrepreneurial farmers. After exploration, the causes of formal financial credit constraints of entrepreneurial farmers in China are mainly as follows.

\subsection{Reasons for Being a Formal Financial Institution of the Supplier}

\subsubsection{The Credit System Is Imperfect, and Financial Institutions Are "Fear of Lending"}

The first is the credit management mechanism. At present, the formal examination and approval authority of formal financial institutions is closed, lacking the right to make independent decisions. At the same time, due to the complicated procedures for the application of loans from entrepreneurial enterprises relative to other enterprises, the long period of time, the number of links and the small amount of loans and the urgency of time make formal financial institutions the credit management cost of farmers has risen. Under the premise that formal financial institutions aim at profitability, rising management costs affect the enthusiasm of formal financial institutions for lending, which in turn will affect the satisfaction of entrepreneurs to obtain loans from formal financial institutions [15]. Second is the credit accountability system. Due to the economic downturn in the domestic economy, the non-performing loan ratio of formal financial institutions has gradually increased. In order to reduce the generation of bad debts and prevent the rise of non-performing loan ratios, formal financial institutions have implemented strict credit accountability systems. This means that the decision-making power and risk responsibility of credit officers of formal financial institutions are correspondingly increased. Therefore, in order to reduce the risk of liability, credit officers began to have a "fear of lending" mentality for entrepreneurial farmers with less mortgage guarantees and low credit ratings. This "fear of lending" psychology has become a threshold for formal financial credit for entrepreneurial farmers. 


\subsubsection{Financial Costs Are High, and Financial Institutions "Repay Loans"}

The principal return cost of the loans provided by the formal financial institutions to the entrepreneurial farmers, the information cost of obtaining the farmer's entrepreneurship and the transaction cost of the market are relatively high. First, formal financial institutions need to have a comprehensive understanding of the assets, credits, and operating conditions of entrepreneurial farmers before granting loans. However, compared with the growing number of entrepreneurial farmers in the country, entrepreneurial materials are more transparent and transparent. Less, before China has yet to establish a personal credit system, formal financial institutions need to put a lot of energy into the credit rating of entrepreneurial farmers, which requires a lot of cost to pay attention to and understand, in order to reduce credit risk. This information asymmetry between formal financial institutions and scattered entrepreneurial farmers, combined with the lack of formal financial institutions' effective guidance for entrepreneurial farmers, enables formal financial institutions to obtain information and services for the financing of entrepreneurial farmers. The cost is relatively high. It has led to the cautious involvement of formal financial institutions in the financing of agricultural funds, so the demand for formal credit funds of entrepreneurial farmers has been correspondingly suppressed. Secondly, in credit marketing, formal financial institutions generally aim at maximizing profits. After the loans are issued, the problem of recovery of funds must be considered. Since the entrepreneurial farmer can mortgage the land, real estate and other non-moving assets are relatively small. In order to reduce credit risk, reduce risk costs and improve asset quality, formal financial institutions generally choose to raise credit thresholds and reduce credit supply, thus creating a phenomenon of "repaying loans" and directly reducing entrepreneurship.

\subsection{Reasons for Starting a Business as a Demanding Farmer}

\subsubsection{Insufficient Mortgage Guarantee}

Farmers' entrepreneurship began in the 1980s. However, the difficulty of starting a farmer's loan is a long-standing problem. One of the important factors is that entrepreneurial farmers lack collateral. As the state's support for farmers' entrepreneurial behavior continues to increase, the financing needs of entrepreneurial farmers for formal financial institutions are increasing. For the traditional lending methods of formal financial institutions, it is difficult for entrepreneurial farmers to provide collateral collateral that meets the requirements. For most entrepreneurial farmers, their own fixed assets are less, and the collateral that can be provided is mainly residential, however both the Property Law and the Guarantee Law clearly stipulate that homesteads may not be mortgaged. In the case that the collateral such as houses, equipment, factories and land has not been fully developed, most of the "real estates" of the entrepreneurial farmers can only be in a "sleeping" state for a long time. The lack of effective mortgage guarantees restricts the turnover of funds in the process of farmers' entrepreneurship, and cannot easily obtain credit support from formal financial institu- 
tions, making entrepreneurial behaviors of entrepreneurial farmers difficult. On the other hand, even with collateral, the cost of a formal financial institution's valuation of mortgage collateral is high. Moreover, in the event of a default, these mortgage collaterals are also difficult to dispose of. Therefore, for most entrepreneurial farmers, the formal credit thresholds of formal financial institutions make them prefer private credits with relatively high interest rates but simple procedures and no mortgages and guarantees.

\subsubsection{The Credit Rating Is Not High}

Affected by traditional ideological concepts, the concept of credit in entrepreneurial farmer groups is not strong, and the phenomenon of defaulting on debts and debts has occurred from time to time. Especially in some rural areas, farmers who "run the road" because of entrepreneurial failure are also commonplace. Most of the entrepreneurial farmers are not long enough for entrepreneurial time, lacking the necessary historical credit records, and can reflect that the specific information of entrepreneurial activities is not detailed enough. Therefore, there is a problem of asymmetric information between entrepreneurial farmers and formal financial institutions. Although under normal circumstances, entrepreneurial farmers will have a relatively small loan amount at the beginning of their business, there are still some entrepreneurial farmers who have not repaid their loans within the prescribed time limit due to their business or other reasons after applying for a small loan phenomenon. Only 54 of the 102 people who applied for a secured loan in 2009 did not repay at the specified time [16], which caused the formal financial institutions to worry about issuing loans and withdrawing funds, so they had to increase the review and release of loans and delay the issuance. At the time of the loan, some formal financial institutions even raised the threshold for issuing loans, and many entrepreneurial farmers with capital needs were excluded.

\subsection{Reasons for Government Support}

\subsubsection{Policy and Regulations Support Is Not in Place}

In recent years, the state has continuously introduced some policies to support the entrepreneurial development of farmers, in order to effectively solve the problem of borrowing loans for some entrepreneurial farmers. Although the state and relevant departments have implemented relevant policies to a certain extent, the measures have not been put in place in the implementation of policies, and for some entrepreneurial farmers, such as the group of landless entrepreneurs, the state has not introduced operational and applicable characteristics for the group. Sexually strong formal financial support policies, coupled with the fact that some entrepreneurial farmers have little understanding of China's financial policies, and some relevant mortgage subsidies and policy credit support are under-understood, leading to the relevant government departments in China. Some entrepreneurial policies that are conducive to farmers are difficult to implement. Coupled with the poor timeliness of financial policies and the lack of 
credit products for specialized entrepreneurial households, the expected support effect of relevant formal financial loan products is difficult to implement. This also restricts the credit needs of entrepreneurial farmers to a certain extent.

\subsubsection{The Credit Guarantee System Is Not Perfect}

In order to solve the situation of financial credit constraints of entrepreneurial farmers in rural areas in China, relevant government departments have repeatedly mentioned that the formation of credit systems in rural areas should be accelerated, and a rural financial credit guarantee system with government support and participation by many parties should be created. Although China's rural credit cooperatives have promoted the loan for rural entrepreneurship since 1999, the difference between the guarantee mechanism of rural enterprises and the actual conditions of rural entrepreneurship is still very large. The mortgage discount rate of secured mortgage and credit lending is too high, which leads to the lack of sufficient financial support for entrepreneurial farmers; the lack of sufficient trust between formal financial institutions and guarantee institutions; information asymmetry and risk management to be legalized, etc. The current situation limits the growth of entrepreneurial farmers and the normal operation of secured mortgage institutions. Therefore, relying solely on the behavioral choices of the formal financial institutions and the encouragement of the state, there is no way to promote the effective development and development of formal financial credit. Therefore, the formal financial credit constraints of the majority of entrepreneurial farmers will continue in the long run.

\subsubsection{Unreasonable Allocation of Financial Resources in Rural Areas}

According to the survey, the looting of financial resources by large enterprises and local governments has a strong squeeze effect on entrepreneurial farmers and small businesses. Local governments use their hands to intervene indirectly through calls and other forms of loans, and they have squeezed out many formal financial credits to engage in non-financial activities, leading to a gap in the formal financial resources that are scarce. For example, some local governments also require formal financial institutions to provide credit to some poorly-developed township and village enterprises, resulting in the precipitation and loss of formal financial institutions' credit in a small number of industries and projects. The credit resources of financial institutions to be regulated meet certain government concerns. In some projects, the credit resources of formal financial institutions have been divided, so that they cannot meet the formal financial credit needs of entrepreneurial farmers.

\section{The Countermeasures to Alleviate the Formal Financial Credit Constraints of Entrepreneurial Farmers}

By combining the current situation of supply and demand of formal financial credits of entrepreneurial farmers, we have analyzed and understood the reasons for the formation of formal financial credit constraints of entrepreneurial farmers in the previous article. With the increasing attention of the development of 
entrepreneurial farmers in China. The formal financial credit support system needed has become an urgent task for promoting the development of entrepreneurial farmers in China. However, to alleviate the problem of formal financial credit constraints for entrepreneurial farmers, it is impossible to rely solely on the efforts of entrepreneurial farmers. It requires the joint cooperation of formal financial institutions, governments and entrepreneurial farmers, and comprehensive measures to achieve a win-win situation for entrepreneurial farmers and formal financial institutions.

\subsection{Reform Measures of Formal Financial Institutions}

\subsubsection{Improve the Credit Management Mechanism and Strengthen the Financial Service Function}

The first is to improve the loan authorization system and solve the loan bottleneck of entrepreneurial farmers. Formal financial institutions should comply with the credit characteristics of entrepreneurial farmers, properly decentralize loan authority, speed up the approval of credit for entrepreneurial households, optimize the credit approval process, and improve work efficiency, thereby reducing the cost of credit management. Second, we should improve the loan marketing system. It is necessary to solve the situation of employees who are engaged in credit work, and at the same time, through the evaluation indicators such as the number of loans and the amount of loans of entrepreneurial farmers, the credit evaluation mechanism for entrepreneurial farmers is continuously improved, and the performance of credit officers is regular. Financial institutions have combined the development of the business of granting loans for entrepreneurial farmers, encouraging credit officers to actively cultivate and develop entrepreneurial farmer customers, and increase credit investment for entrepreneurial farmers.

\subsubsection{Improve the Mortgage Guarantee Method and Ease the Credit Restrictions of Farmers}

In order to solve the problem of insufficient mortgage guarantee for entrepreneurial farmers, when formal financial institutions lend to entrepreneurial farmers, they can expand the types of assets that can be mortgage-guaranteed by entrepreneurial farmers, such as construction projects, intangible assets, and land contracting rights in the establishment of farmer households in China. The accounts receivable are regarded as collateral assets and the mortgage guarantee method of the project itself, which alleviates the problem that the entrepreneurial farmer's collateralized assets can be insufficient. At the same time, it can also actively implement the form of joint guarantee loans to effectively solve the problem of insufficient mortgage guarantee for entrepreneurial farmers. That is to say, three or more entrepreneurial farmers form a consortium, and each has a joint guarantee responsibility. Since entrepreneurial farmers generally pay much attention to their own credibility in the village, the use of joint insurance can reduce the default rate of entrepreneurial farmers, which is conducive to the security of credit funds of formal financial institutions. In this way, it can effec- 
tively solve the current situation of insufficient mortgage guarantee in the financing process of entrepreneurial farmers, reduce the credit risk of formal financial institutions, and greatly increase the success rate of entrepreneurial farmers to obtain formal financial credit.

\subsection{Countermeasures for Credit Enhancement of Entrepreneurial Farmers}

\subsubsection{Improve Your Qualifications and Credit Rating}

Faced with the constraints of formal financial credit, entrepreneurial farmers should strive to improve their qualifications and credit ratings, and make efforts to obtain credit support from formal financial institutions. First, we must accelerate the accumulation of capital and increase the stock of fixed assets, with a view to appropriately alleviating the dilemma of effective guarantees. At the same time, we should establish a modern entrepreneurial system by means of joint ventures and joint-stock systems, improve the corporate governance structure, and change through scientific operation management. The financing dilemma caused by the "one big share" of entrepreneurial farmers. Second, entrepreneurial farmers should strengthen their management and improve the transparency of information in entrepreneurial activities. In the actual work management, entrepreneurial farmers should strengthen the credibility of entrepreneurial activities and establish a good image of integrity. Only in this way can we obtain the trust of the supply side to the entrepreneurial farmers in China, thus reducing the credit constraints that exist in the entrepreneurial activities.

\subsubsection{Strengthen Self-Learning and Raise Financial Awareness}

Affected by traditional ideas, credit awareness has not attracted much attention in rural financial markets. Entrepreneur farmers should learn to truly understand the principle of "repaying debts and paying back money", improve their financial credit awareness, and prevent malicious escape of debt occur. At the same time, we must understand the financial services of China's formal financial institutions, deeply understand the government's financial support for "agriculture, rural areas and farmers", use the government's financial support for entrepreneurial farmers, learn the country's credit support programs, and shift from the traditional high-interest "private lending". Formal financial institutions to finance reduce financing costs and improve the benefits of entrepreneurial behavior.

\subsection{Thoughts on the Improvement of the Government Support System}

\subsubsection{Increase Policy Support and Implement It in Place}

While encouraging formal financial institutions to lend to entrepreneurial farmers, the state should follow up a series of specific policy support measures such as government incentives, tax incentives and interest subsidy policies. Actively promote the equalization of entrepreneurial farmers in China to participate in the reform of state-owned enterprises and social welfare projects. At the same 
time, it simplifies the procedures for applying for approval, and opens a "green channel" for the entrepreneurship of Chinese farmers. Of course, while providing efficient and convenient services, government departments should increase the propaganda of the promulgation policy and guide entrepreneurial farmers to pay more attention to national financial policies, such as organizing financial policy lectures for entrepreneurial farmers, so that more farmers can We can understand the existence of government policies and deepen the understanding and application of a series of policies such as interest subsidy policies and guarantee policies. The relevant departments of the government must implement relevant policies and use various channels and channels to enable the government's policy support for entrepreneurial farmers to effectively solve the formal financial credit constraints of entrepreneurial farmers.

\subsubsection{Reasonably Allocate Financial Resources to Meet the Credit Needs of Entrepreneurial Farmers}

Local governments should strictly implement China's financial support measures for entrepreneurial farmers, and legally and harmonize the allocation of limited rural financial resources. It should clearly recognize that promoting the entrepreneurial development of farmers is their responsibility, and providing entrepreneurs with credit demand. The Green Channel ensures that entrepreneurial farmers can get the money they need to start a business. When the formal financial institutions allocate the annual loan quota, they should allocate a certain credit line for the entrepreneurial farmers. The local governments should mainly support the entrepreneurs' entrepreneurship, and the credit quotas should be fair and reasonable to meet the credit needs of the entrepreneurial farmers. Establish a transparent supervision mechanism to ensure that the state's support policies for farmers' self-employment are implemented.

\subsubsection{Improve the Household Credit Information System and Reduce the Credit Risk of Formal Financial Institutions}

First, the relevant government departments should help more entrepreneurial farmers to establish a sound credit platform. Relevant government departments can integrate the integrity of entrepreneurial farmers in China into a unified national credit system by carrying out the work of honesty and entrepreneurship of entrepreneurial farmers. The wider the range of credit information collected by entrepreneurial farmers, the more comprehensive and detailed the content will be. Entrepreneurial farmers with good credit can obtain credit demand, and at the same time, they can reduce the credit risk of formal financial institutions and reduce the corresponding information costs and management costs. The second is to establish an effective credit supervision mechanism for entrepreneurial farmers through the formulation of corresponding measures. Relevant government departments can create a good environment for breaking the formal financial credit constraints of entrepreneurial farmers by using institutional guarantees, policy coordination and incentives for formal financial institutions to innovate financial services products. 


\section{Conflicts of Interest}

The author declares no conflicts of interest regarding the publication of this paper.

\section{References}

[1] (2015) The Full Text of the Communique of the Fifth Plenary Session of the 18th Central Committee. China Radio Network. http://www.qing5.com/

[2] Zhang, Y.L., Gao, J. and Zhang, J.F. (2015) Research on the Formal Financial Credit Constraint of Entrepreneurial Farmers-An Empirical Analysis Based on 939 Farmer Entrepreneurial Surveys. Agricultural Technology \& Economy, 1, 64-74.

[3] Shi, L.J. (2014) Analysis of the Degree of Regular Financial Credit Rationing and Influencing Factors of Farmers in Guanzhong. Thesis, Northwest A\&F University, Xianyang.

[4] Yan, Z.J. and Zhang, B. (2005) Analysis of the Characteristics of Chinese Farmers' Credit and Its Influencing Factors. Agricultural Technology Economy, 4, 2-4.

[5] Lu, Y.J., Zhang, L.Y. and Xu, Y.Z. (2014) Financial Availability and Rural Family Entrepreneurship-An Empirical Study Based on CHARLS Data. Economic Theory and Business Management, 10, 89-99.

[6] Chen, C., Zhou, L.D. and Wang, A.L. (2011) Research on Characteristics of Farmers' Financing Behavior. Journal of Agricultural Sciences, 7, 52-55.

[7] Ping, X.Q., Zhang, H.Y. and Liang, S. (2012) A Probe into the Causes of Farmers' Financial Constraints. Economics, 4, 10-14.

[8] Black, S.E. and Strahan, P.E. (2010) Entrepreneurship and Bank Credit Availability. Journal of Finance, 57, 2807-2833. https://doi.org/10.1111/1540-6261.00513

[9] Chen, C.Y. (2009) Reflections on the "Difficulty of Loans" for Farmers and Small and Medium-Sized Enterprises and the "Difficult Loans" of Financial Institutions. Economist, 2, 206-207.

[10] Ma, J.J. (2008) Social Capital and Farmer Economy. China Agricultural Science and Technology Press, Beijing.

[11] Ping, X., Zhang, H., Liang, S. and Hao, C. (2012) Farmers' Entrepreneurial Choice and Its Influencing Factors-Evidence from Rural Financial Investigation. China Rural Economy, 4, 57-95.

[12] Zhang, D. (2013) Some Thoughts on Cracking the Financing Problem of New Agricultural Management Subjects. Henan Agriculture, 11, 6-8.

[13] Wang, Y. (2011) Analysis of Rural Informal Finance from the Perspective of Credit Supply and Demand. Economic Research Guide, 33, 35-37.

[14] Ping, X., Zhang, H., Liang, S. and Hao, Z. (2015) Financial Constraints in Social Capital and Farmers' Entrepreneurship-Based on the Research of Rural Financial Survey Data. Zhejiang Social Sciences, 7, 15-27.

[15] Zhu, Y. (2012) Research on the Factors Affecting Farmers' Microfinance Demand and Credit Constraint. Zhejiang University of Finance and Economics, 11, 34-52.

[16] Ge, Z. and He, J. (2012) Fund Bottleneck Factors Restricting Farmers' Self-Employment and Their Countermeasures. Employment of Migrant Workers, 29-30. 